\title{
RAGAM BAHASA SERAT KALATIDHA SERTA RELEVANSINYA DALAM PEMBELAJARAN BAHASA JAWA SISWA SMP NEGERI 7 YOGYAKARTA
}

\author{
Chinda Pandu Permana ${ }^{1)}$, Endang Nurhayati ${ }^{2)}$ \\ SMP Negeri 7 Yogyakarta ${ }^{1)}$, Universitas Negeri Yogyakarta ${ }^{2)}$ \\ chindaPandu@yahoo.com ${ }^{1)}$, endang_fbs@yahoo.com ${ }^{2)}$
}

\begin{abstract}
Abstrak
Penelitian ini bertujuan untuk mendeskripsikan jenis ragam bahasa dan nilai sosial budaya dalam serat Kalatidha, serta kerelevansian diksi serat Kalatidha terhadap pembelajaran. Jenis penelitian adalah campuran. Subyek penelitian adalah serat Kalatidha, objek penelitian adalah jenis ragam dan nilai sosial budaya dalam serat Kalatidha. Populasi penelitian ini adalah siswa SMP N 7 Yogyakarta, sampel penelitian yaitu siswa kelas IX SMP N 7 Yogyakarta. Metode pengumpulan data yaitu simak, catat, dan tes. Instrument penelitian yaitu peneliti sendiri, kolom data, dan tes. Keabsahan data dilakukan dengan pemeriksaan. Analisis data dilakukan dengan klasifikasi dan menggunakan software AnatesV4. Hasil penelitian yaitu, (1) jenis ragam dalam serat Kalatidha antara lain ragam tidak resmi, sastra, jengkel, sedih, senang, bingung, mantap, bimbang, malu, kreatif, beku, dan filosofis, (2) nilai sosial budaya yang ada antara lain bahasa, strata sosial, sistem pemerintahan, sistem religi, dan sistem pengetahuan, (3), diksi serat Kalatidha tidak relevan dalam pembelajaran bahasa Jawa SMP.
\end{abstract}

Kata kunci: ragam bahasa, serat Kalatidha

\section{LANGUAGE STYLE IN SERAT KALATIDHA AND ITS RELEVANCE TO THE TEACHING OF JAVANESE LANGUAGE}

\begin{abstract}
This research is aimed at describing the types of styles and socio-cultural values in Serat Kalatidha, and knowing the relevance of the word in Serat Kalatidha when used as a teaching material. This research was a mixed research. The research subject was Serat Kalatidha, the research object was the types of styles and socio-cultural values in Serat Kalatidha. The population for this research was all students of SMP $N 7$ Yogyakarta, while the sample was the students of grade IX. of this school. The data collection employed the method of simak (read), catat (write), and test. The instrument was the researcher himself, data columns, and test.The data validity was proved by employing the checking technique.The data analysis was done by classification and using the anatesV4 program. The findings are: (1) the types of styles found in serat Kalatidha are informal, literary, annoying, sad, happy, confused, sure, anxious, embarrassed, creative, frozen, and philosophical; (2) the analysis on the socio-cultural context finds elements of language, social hierarchy, governance system, religion system, and education system; (3) the word in serat Kalatidha are not appropriate to be used as a teaching material in the teaching of Javanese language to grade IX students of SMP N 7 Yogyakarta.
\end{abstract}

Keywords: language style, Serat Kalatidha 


\section{PENDAHULUAN}

Naskah merupakan salah satu karya sastra yang ditulis oleh pengarang untuk mengekspresikan fenomena kehidupan, keadaan sosial masyarakat, maupun pemerintahan pada zaman dulu. Naskah juga dapat digunakan sebagai pedoman kehidupan masyarakat karena dalam naskah terdapat nilai-nilai moral, etika, kepemimpinan, dan lain sebagainya. Pengarang biasanya menggunakan variasi bahasa dalam naskah untuk menyampaikan pesan dan mengungkapkan fenomena yang sedang dirasakan.

Salah satu naskah yang ditulis oleh Ranggawarsita adalah serat Kalatidha. Sebagai salah satu karya sastra, serat Kalatidha menggambarkan keadaan sosial masyarakat pada masa itu. Penelitian ini menggunakan serat Kalatidha sebagai subjek penelitian dikarenakan isi dari serat Kalatidha relevan dengan kehidupan saat ini, kaitannya dengan sistem pemerintahan. Isi serat Kalatidha disampaikan menggunakan ragam bahasa. Ragam yang digunakan sangat bervariatif, karena didukung dengan bahasa yang indah, dan kosakata yang memiliki nilai sastra tinggi. Selain itu, ragam yang digunakan dalam serat Kalatidha juga mempunyai nilai filosofis yang dapat diterapkan dalam kehidupan saat ini.

Ragam dalam serat Kalatidha berfungsi menunjukkan keadaan sosial masyarakat pada waktu itu. Ragam bahasa dalam serat Kalatidha mengandung pesan dan amanat yang perlu digali untuk direfleksikan dalam kehidupan saat ini. Selain itu, pemahaman tentang ragam bahasa sangat dibutuhkan oleh masyarakat khususnya dalam pendidikan formal.

Serat Kalatidha sebagai karya besar telah menarik perhatian banyak orang, sehingga pengkajian terhadap naskah karya Ranggawarsita tersebut sangat banyak dilakukan dari berbagai aspek. Misalnya pemaparan Puji Santosa (2010) yang mendeskripsikan isi dan nilai kepemimpinan dalam serat Kalatidha. Ia menekankan pada bagian pupuh zaman edan yang menceritakan morat-maritnya pemerintahan pada masa itu. Pemaparannya diungkapkan dalam sebuah buku berjudul Kekuasaan Zaman Edan yang berisikan tanda-tanda zaman edan. Pemaparan tersebut merupakan pendeskripsian isi dari serat Kalatidha.

Selain itu, Andjar Any (1989) dalam bukunya Rahasia Ramalan Jayabaya Ronggawarsita dan Sabda Palon juga memaparkan isi serat Kalatidha yang menekankan aspek sosial pemerintahan. Mengingat bahwa serat Kalatidha sebagai karya pujangga ternama dan isinya juga sangat relevan dalam kehidupan, tentu masih banyak pengkajian naskah dari aspek yang lain.

Berdasarkan kedua pengkaji serat Kalatidha tersebut dapat disimpulkan bahwa serat Kalatidha memiliki daya tarik untuk dikaji, karena isinya sangat relevan dalam kehidupan saat ini terkait dengan sistem pemerintahan. Pengkajian terhadap serat Kalatidha sangat perlu dilakukan mengingat generasi muda saat ini kurang begitu peduli terhadap kebudayaan lokal. Diharapkan dengan penelitian ini, serat Kalatidha dapat diketahui oleh masyarakat khususnya generasi muda.

Penelitian ini meneliti serat Kalatidha dari segi bahasa dan konteks sosial budaya. Aspek bahasa yang diteliti kaitannya dengan ragam bahasa. Ragam bahasa yang telah didapat kemudian diteliti apakah relevan atau tidak jika digunakan sebagai materi pembelajaran bahasa Jawa siswa SMP N 7 Yogyakarta. Penentuan tingkat pendidikan SMP berdasarkan peninjauan dalam buku ajar Kaloka Basa siswa SMP kelas IX. Dalam buku tersebut terdapat materi yang diambil dari pupuh serat Kalatidha bagian zaman edan. Cara yang ditempuh untuk mengetahui kerelevansian diksi yaitu dengan cara tes. Soal disusun berdasarkan pedoman pembuatan soal tingkat SMP. Peneliti menggunakan standar KKM untuk menentukan kerelevansian diksi serat Kalatidha dalam pembelajaran bahasa Jawa siswa kelas IX SMP.

\section{METODE PENELITIAN}

Penelitian ini menggunakan pendekatan kualitatif dan kuantitatif, sehingga merupakan penelitian campuran (mixed method). Menurut Brannen (2005, p.44), "metode gabungan dapat berakhir dengan dua studi terpisah tetapi berhubungan, yang satu sama lain berbeda pada setiap tahap proses penelitian”.

Pendapat Brannen tersebut sesuai dengan penelitian ini, yaitu menggabungkan dua metode yang berbeda (kualitatif dan kuantitatif) namun memiliki keterkaitan. Penelitian dengan pendekatan kuantitatif dilakukan di SMP N 7 Yogyakarta. Berkaitan dengan waktu, penelitian kualitatif dilakukan secara fleksibel. Maksudnya, penelitian kualitatif tersebut tidak terikat oleh waktu. Penelitian dapat dilakukan kapanpun sesuai kehendak peneliti. Penelitian dengan pendekatan kuantitatif dilakukan pada tanggal 25 Februari sampai dengan 2 Maret 2013. 
Subjek penelitian ini adalah serat Kalatidha karya Ranggawarsita. Objek penelitian adalah jenis ragam bahasa dan nilai sosial budaya yang terdapat dalam serat Kalatidha karya Ranggawarsita.

Populasi penelitian ini adalah semua siswa SMP N 7 Yogyakarta. Sampel penelitian ini adalah siswa kelas IX SMP N 7 Yogyakarta pa-da tahun ajaran 2012/2013.

Penelitian ini menggunakan beberapa teknik pengumpulan data, karena desain penelitian yang digunakan adalah campuran (mixed method). Metode yang digunakan untuk menggumpulkan data adalah metode simak dengan teknik lanjutan catat. Selain itu, kaitannya dengan penelitian kuantitatif, peneliti menggunakan metode tes untuk mengumpulkan data.

Instrumen pengumpulan data dalam penelitian ini adalah peneliti sendiri yang memanfaatkan kolom data dalam pemerolehan data. Berkaitan dengan penelitian kuantitatif, instrumen yang digunakan untuk mengumpulkan data adalah tes. Tes yang digunakan adalah tes dalam bentuk pilihan ganda.

Validitas instrumen yang digunakan dalam penelitian ini adalah validitas isi dan validitas konstruk. Validitas isi didapatkan melalui proses telaah orang yang lebih ahli, yaitu Prof. Dr. Endang Nurhayati, dan juga memerlukan peran validator, yaitu Prof. Dr. Suwarna. Validitas konstruk dilakukan dengan cara meninjau kembali instrumen tes dari segi keilmuan.

Keabsahan data didapatkan dengan teknik pemeriksaan. Kriteria yang digunakan sebagai dasar teknik pemeriksaan dalam penelitian ini adalah derajat kepercayaan. Untuk mengetahui derajat kepercayaan data terkait ragam bahasa dalam serat Kalatidha serta konsep sosial budaya yang ada, penelitian ini menggunakan teknik pemeriksaan perpanjangan penelitian, ketekunan pengamatan, triangulasi, serta pemeriksaan sejawat melalui diskusi.

Analisis data dilakukan dengan metode padan intralingual dan teknik klasifikasi. Metode padan intralingual digunakan berdasarkan aspek makna dan konteks. Jadi, peneliti menganalisis data berdasarkan makna dan konteks yang menyertai data yang didapatkan. Data yang telah dianalisis kemudian diklasifikasikan berdasarkan bagian-bagian.
Sementara itu, analisis data terkait pendekatan kuantitatif dilakukan dengan bantuan software program AnatesV4. Penggunaan software ini bertujuan untuk mengetahui nilai yang dicapai siswa, sehingga dapat diketahui tingkat kerelevanan ragam bahasa serat Kalatidha jika diterapkan dalam pembelajaran bahasa Jawa. Penarikan kesimpulan menggunakan standar KKM yang diberlakukan sekolah.

\section{HASIL PENELITIAN DAN PEMBAHASAN}

\section{Hasil Penelitian}

\section{Jenis Ragam dalam Serat Kalatidha Karya Ranggawarsita}

Penelitian ini menemukan ragam bahasa yang terdapat dalam serat Kalatidha karya Ranggawarsita. Ragam yang paling banyak digunakan adalah ragam sastra atau ragam indah. Hal tersebut tampak dari penggunaan kosakata, frasa, maupun kalimat dalam tiap-tiap pupuh serat Kalatidha. Ragam sastra maupun ragam indah ini ditandai dengan penggunaan purwakanthi. Menurut Padmosoekotjo (1958, p.100), purwakanthi didefinisikan sebagai berikut:

purwakanthi ateges nggandheng kang wis kasebut ana ing purwa utawa wiwitan. Maksudte: perangan kang buri nggandheng kang wis kasebut ana ing perangan wiwitan utawa purwa, utawa kang wis kasebut ana ing perangan ngarep, wondene kang digandheng iku swarane utawa aksarane, terkadang tembunge. (purwakanthi berarti menggandeng yang sudah disebutkan di depan atau awalan. Maksudnya: bagian yang dibelakang mengikuti yang sudah ada di bagian awalan atau depan, atau yang sudah disebut di bagian depan, sedangkan yang digandeng itu suaranya atau hurufnya, kadang-kadang katanya).

Berdasarkan teori tersebut, maka peneliti dapat menyimpulkan bahwa ragam yang mendominasi dalam serat Kalatidha karya Ranggawarsita adalah ragam sastra atau ragam indah, karena dalam serat Kalatidha banyak digunakan purwakanthi. Selain itu, adanya purwakanthi menuntut kekreatifan pengarang, sehingga munculnya purwakanthi juga disertai dengan adanya ragam kreatif. Jenis ragam yang tidak ditemukan yaitu ragam resmi dan ragam marah. Berikut pemaparan hasil penelitian. 
Tabel 1. Jenis Ragam dalam Serat Kalatidha Karya Ranggawarsita

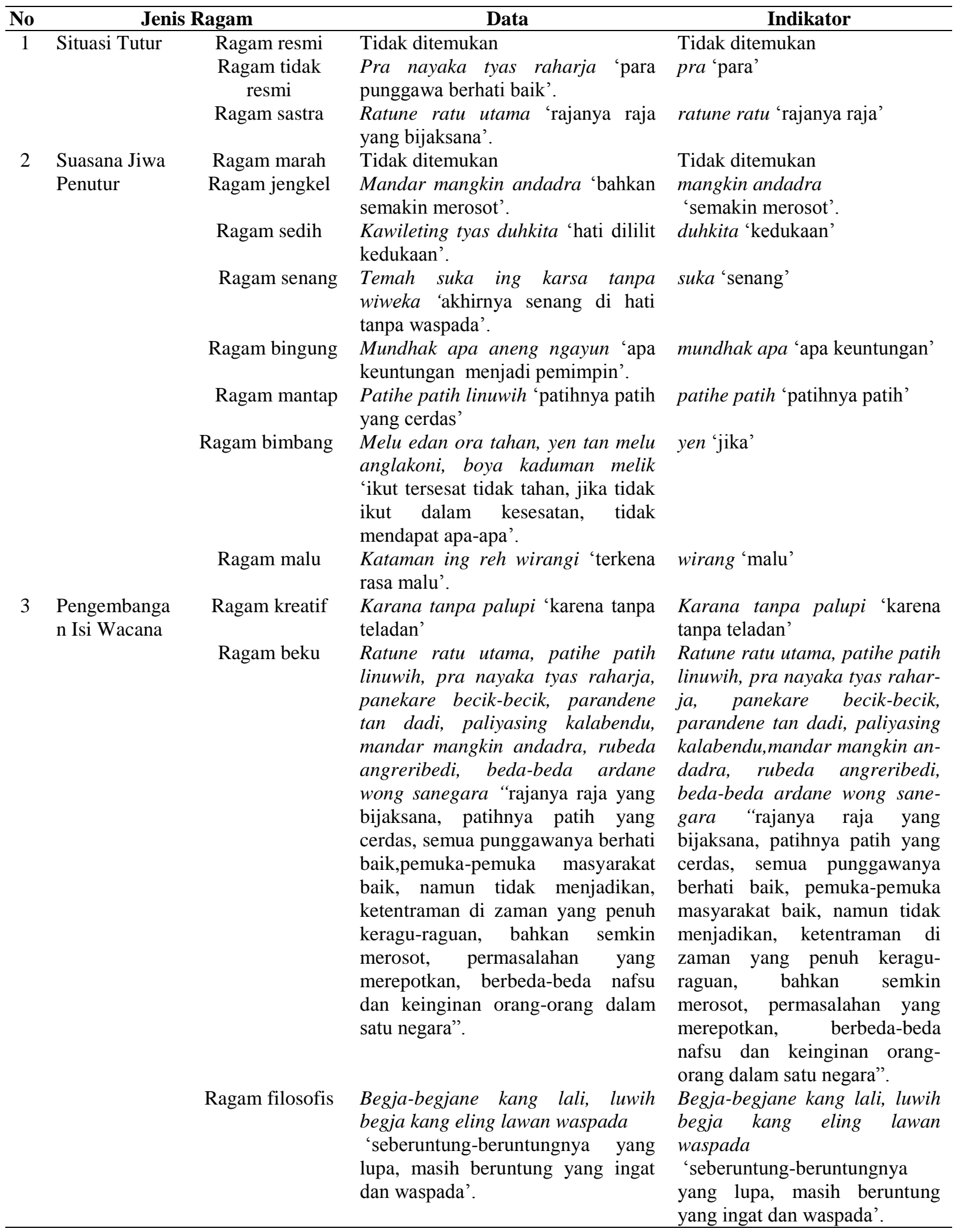

Konteks Sosial Budaya dalam Serat Kalatidha Karya Ranggawarsita

Penelitian ini menemukan aspek sosial budaya masyarakat pada masa Ranggawarsita yang teridentifikasi berdasarkan ragam bahasa serta isi dari serat Kalatidha. Sistem sosial budaya yang ditemukan bertolak pada unsur kebudayaan yang diakui di dunia yang dikemas menjadi tujuh unsur kebudayaan. Ketujuh unsur 
kebudayaan tersebut menurut Koentjaraningrat (2009, p.81) terdiri atas bahasa, sistem pengetahuan, organisasi sosial dan kepemimpinan masyarakat, sistem peralatan hidup dan teknologi, sistem mata pencaharian hidup, sistem religi, serta kesenian. Berikut hasil penelitian terkait dengan konteks sosial budaya yang terdapat dalam serat Kalatidha karya Ranggawarsita.

Tabel 2 Konteks Sosial Budaya dalam Serat Kalatidha Karya Ranggawarsita

\begin{tabular}{|c|c|c|}
\hline No & $\begin{array}{c}\text { Kontek sosial } \\
\text { budaya }\end{array}$ & Indikator/penanda \\
\hline 1 & Bahasa & $\begin{array}{l}\text { Bahasa sebagai bagaian } \\
\text { dari unsur budaya tampak } \\
\text { pada naskah secara } \\
\text { keseluruhan. }\end{array}$ \\
\hline 2. & Strata sosial & $\begin{array}{l}\text { Ratu 'raja', patih 'patih', } \\
\text { nayaka 'pemimpin', }\end{array}$ \\
\hline 3. & $\begin{array}{l}\text { Sistem } \\
\text { pemerintahan }\end{array}$ & $\begin{array}{l}\text { Praja 'negara', ratu 'raja', } \\
\text { patih 'patih', nayaka ' } \\
\text { punggawa'. }\end{array}$ \\
\hline 4. & $\begin{array}{l}\text { Sistem religi/ } \\
\text { keyakinan }\end{array}$ & $\begin{array}{l}\text { Mupus pepesthening takdir } \\
\text { 'berpasrah pada kehendak } \\
\text { takdir, karsa Allah } \\
\text { 'kehendak Tuhan', Hyang } \\
\text { Suksma 'Tuhan', Pangeran } \\
\text { 'Tuhan', parmaning } \\
\text { Suksma 'rahmatnya Tuhan' } \\
\text { ya Allah ya Rasulu'llah' } \\
\text { ya Tuhan ya Rosul'. }\end{array}$ \\
\hline 5. & $\begin{array}{l}\text { Sistem } \\
\text { pengetahuan }\end{array}$ & $\begin{array}{l}\text { Sujana sarjana 'orang } \\
\text { cerdik cendekiawan' }\end{array}$ \\
\hline
\end{tabular}

Berdasarkan tabel 2 terkait dengan konteks sosial budaya dalam serat Kalatidha karya Ranggawarsita di atas dapat disimpulkan bahwa aspek yang paling banyak muncul dalam serat Kalatidha adalah sistem religi atau keyakinan. Sistem religi ini dapat dilihat dalam pupuh 6, 7, $8,9,10,11$, dan 12 . Hal ini dapat terjadi karena Ranggawarsita seorang pujangga yang berbudi pekerti luhur, memiliki sikap seorang kesatria, serta memiliki keyakinan penuh terhadap Tuhan.

Konsep ketuhanan dalam naskah sangat tampak diutarakan oleh Ranggawarsita ketika dirinya dalam posisi yang sangat membutuhkan pertolongan. Ia lalu menyampaikan isi hatinya kepada Tuhan melalui karya sastra serat Kalatidha. Aspek berikutnya yang juga tampak dalam serat Kalatidha adalah sistem pemerintahan. Konsep ini tampak pada pupuh 1, 2, dan 4. Pada dasarnya, isi serat Kalatidha merupakan curahan kekecewaan hati Ranggawarsita terhadap pemerintahan pada waktu itu.
Selain kedua aspek di atas, juga tampak strata sosial dan sistem pengetahuan, yang masing-masing dapat dilihat pada pupuh 2 dan pupuh 1 . Sementara itu, bahasa yang juga merupakan bagian dari unsur kebudayaan tampak pada serat secara keseluruhan yang berperan sebagai media dalam penyampaian curahan hati Ranggawarsita terkait dengan kekecewaan terhadap sistem pemerintahan pada waktu itu. Pada dasarnya kekecewaan Ranggawarsita disebabkan oleh golongan-golongan tertentu yang menggunakan tipu muslihat untuk mendapatkan suatu hal yang diinginkan.

\section{Pembahasan}

Jenis Ragam dalam Serat Kalatidha Karya Ranggawarsita

Penelitian ini menemukan ragam bahasa dalam serat Kalatidha karya Ranggawarsita. Beberapa jenis ragam yang ditemukan sesuai dengan teori yang dipaparkan oleh Endang Nurhayati dalam bukunya Sosiolinguistik Kajian Kode Tutur dalam Wayang Kulit. Namun, tidak semua jenis ragam bahasa tersebut ditemukan. Ada dua jenis ragam bahasa yang tidak ditemukan yaitu ragam resmi dan ragam marah. Berikut pembahasan beberapa ragam bahasa yang ditemukan dalam serat Kalatidha karya Ranggawarsita.

\section{Ragam Tidak Resmi}

Ragam tidak resmi merupakan salah satu bentuk variasi bahasa yang digunakan pada situasi tidak resmi. Salah satu penanda adanya ragam tidak resmi yaitu digunakannya kata-kata wancah, yaitu kata-kata yang dipenggal atau kata yang disingkat. Penggunaan variasi ragam tidak resmi dalam serat Kalatidha karya Ranggawarsita dapat dilihat pada pembahasan berikut.

1) Pra nayaka tyas raharja 'para punggawa berhati baik'. (Andjar Any, 1989, p.25, serat Kalatidha pupuh 2 gatra 3).

Data di atas diambil dari pupuh ke 2 gatra/baris ketiga serat Kalatidha. Adanya ragam tidak resmi ditandai dengan kata yang ditulis tebal yaitu pra "para". Jika disesuaikan dengan silabe yang tepat, maka penulisan kata tersebut seharusnya para "para". Pengarang tentu memiliki alasan mengapa kata tersebut dipenggal sebagian silabenya, yaitu vokal /a/. Berdasarkan konteks yang ada dapat dianalisis bahwa pemenggalan atau tidak digunakannya vokal /a/ pada kalimat tersebut dikarenakan 
adanya aturan tembang yang melekat pada tembang macapat, khususnya tembang sinom pada semua pupuh serat Kalatidha.

Berdasarkan aturan tembang yang melekat pada tembang macapat sinom, jumlah suku kata pada gatra/baris ke tiga tembang sinom yaitu 8 suku kata. Untuk memenuhi aturan tersebut, pengarang tidak mungkin menggunakan kata para 'para' secara utuh tanpa dipenggal sebagian silabenya. Hal tersebut dikarenakan apabila pengarang menggunakan secara utuh, aturan suku kata yang harusnya 8 suku kata tidak akan dapat terpenuhi, karena suku kata menjadi 9. Berdasarkan alasan tersebut, maka pengarang kemudian tidak menuliskan kata para 'para' secara keseluruhan, namun dipenggal sebagian silabenya, yaitu tidak digunakannya vokal /a/ setelah konsonan /p/. Walaupun demikian, hal tersebut tidak mengubah makna, karena maknanya tetap sama yang pada intinya menyatakan keseluruhan.

\section{Ragam Sastra atau Ragam Indah}

Ragam sastra atau ragam indah merupakan bentuk variasi yang banyak ditemukan dalam serat Kalatidha karya Ranggawarsita. Adanya ragam sastra atau ragam indah ini dapat ditandai dengan indikator salah satunya digunakan untuk menggambarkan suasana indah dengan pilihan kata yang indah pula. Keindahan kata dalam ragam indah dapat dilihat dari persamaan bunyi, atau dikenal dengan istilah purwakanthi. Adanya purwakanthi membuktikan kekreatifan pengarang dalam menentukan diksi, sehingga munculnya purwakanthi juga disertai dengan adanya ragam kreatif. Penggunaan variasi ragam sastra yang juga menunjukkan adanya kekreatifan pengarang dalam serat Kalatidha dapat dilihat pada pembahasan berikut.

2) Karana tanpa palupi 'karena tanpa keteladanan'. (Andjar Any, 1989, p.25, serat Kalatidha pupuh 1 gatra 4)

Ragam sastra atau ragam indah dan kekreatifan pengarang pada data 2) tersebut ditandai dengan adanya persamaan bunyi, atau dalam bahasa Jawa dikenal dengan istilah purwakanthi. Ditemukan dua jenis purwakanthi yang digunakan pada data 2) yaitu purwakanthi swara dan purwakanthi sastra. Purwakanthi swara yaitu persamaan bunyi vokal /a/ pada akhir kata karana 'karena' dan tanpa 'tanpa'. Kalimat tersebut akan menjadi tidak indah jika tidak ada persamaan bunyi vokal /a/, misalnya kata karana 'karena' diganti dengan kata jalaran 'karena' yang keduanya memiliki makna hampir sama.

Purwakanthi sastra pada data tersebut ditandai dengan adanya pengulangan konsonan /p/ pada data tanpa palupi 'tanpa teladan'. Apabila kata tersebut ada yang diganti, maka keindahan bunyi tidak dapat dirasakan lagi. Misalnya kata tanpa 'tanpa' diganti dengan ora nganggo 'tidak menggunakan/tanpa', yang keduanya memiliki makna hampir sama. Maka data akan menjadi karana ora nganggo palupi 'karena tidak menggunakan/tanpa teladan'. Disamping tidak indah lagi, aturan tembang yang terikat oleh guru wilangan pun sudah tidak beguna.

\section{Ragam Jengkel}

Ragam jengkel merupakan salah satu bentuk variasi yang berfungsi untuk menyampaikan perasaan atau mewakili rasa jengkel seseorang. Dalam serat Kalatidha, ragam jengkel ini ditandai dengan adanya kosakata yang digunakan yang merujuk pada suasana jengkel. Berikut data ragam jengkel yang diambil dari serat Kalatidha karya Ranggawarsita.

3) Mandar mangkin andadra 'bahkan semakin merosot'. (Andjar Any, 1989, p.25, serat Kalatidha pupuh 2 gatra 7)

Pada data 3) tersebut, terdapat ragam jengkel. Jika dilihat dari pupuh secara keseluruhan, baris-baris sebelum data 3) menceritakan tentang kejanggalan pada zaman Ranggawarsita. Pada dasarnya raja, menteri, dan pemerintah memiliki sifat yang baik. Namun, hal tersebut tidak menjadikan ketentraman dan keadilan. Dari sinilah rasa jengkel Ranggawarsita mulai muncul. Rasa jengkel yang dirasakan Ranggawarsita memuncak dengan ditandai kalimat mandar mangkin andadra 'malah semakin menjadi'. Maksud digunakannya kalimat tersebut menerangkan bahwa walaupun raja, menteri pada masa itu memiliki sifat yang baik, namun tidak dapat merubah keadaan zaman. Bahkan, malah semakin buruk dan semakin tidak tertata. Ia hanya sebatas jengkel terhadap orang-orang munafik dan terhadap fenomena hidup yang menimpa dirinya.

\section{Ragam Sedih}

Ragam sedih merupakan variasi ragam yang digunakan untuk mengekspresikan kesedihan. Dalam hal ini, kosakata ataupun ragam 
yang digunakan memiliki nilai rasa sedih atau bernuansa sedih. Dalam serat Kalatidha terdapat beberapa data yang mencerminkan kesedihan, seperti pada data berikut.

4) Parandene tan dadi 'namun tidak menjadi'. (Andjar Any, 1989: 25, serat Kalatidha pupuh 2 gatra 5)

Untuk mengetahui bahwa data di atas mencerminkan kesedihan yang dirasakan oleh Ranggawarsita, perlu dikaitkan dengan baris sebelumnya serta konteks pupuh yang menyertainya. Pada baris sebelumnya diceritakan bahwa sesungguhnya raja, menteri, dan pejabat negara memiliki sifat yang baik, tertib, pandai, dan disiplin. Dengan situasi seperti itu tentunya sistem pemerintahan akan berjalan dengan baik. Namun, kenyataan yang ada bertolak belakang. Hal ini yang menjadikan hati Ranggawarsita merasa sedih. Sehingga ia menuliskan bahwa walaupun raja, menteri, dan pejabat negeri memiliki sifat yang baik, namun tidak dapat menjadi penolak adanya zaman yang penuh musibah. Pernyataan tersebut diungkapkan dalam kalimat, parandene tan dadi, paliyasing kalabendu 'namun tidak jadi, penolaknya musibah'.

\section{Ragam Senang}

Ragam senang merupakan variasi bahasa yang digunakan untuk menunjukkan rasa senang maupun suasana senang. Dalam serat Kalatidha, terdapat satu ragam senang yang digunakan, walaupun secara keseluruhan serat Kalatidha berisikan rasa kekecewaan Ranggawarsita yang identik dengan rasa sedih. Berikut data yang menunjukkan adanya ragam senang dalam serat kalatidha karya Ranggawarsita.

5) Temah suka ing karsa tanpa wiweka 'akhirnya senang di hati tanpa waspada'. (Andjar Any, 1989, p.25, serat Kalatidha pupuh 3 gatra 9)

Data 5) tersebut adalah data satu-satunya yang menunjukkan adanya ragam senang dalam serat Kalatidha karya Ranggawarsita. Dalam data tersebut, yang merasakan rasa senang adalah Ranggawarsita. Jika dilihat dari konteks secara keseluruhan, banyak orang yang datang untuk menghibur, memberi semangat, dan seolah-olah menawarkan kebaikan, sehingga hati Ranggawarsita merasa senang. Ragam senang ditandai dengan kata suka 'senang'. Namun tanpa disadari bahwa orang-orang tersebut memiliki maksud tersendiri, yaitu untuk mencari keuntungan bagi diri sendiri, sehingga dituliskan bahwa Ranggawarsita merasa senang tanpa waspada.

\section{Ragam Bingung}

Ragam bingung merupakan variasi bahasa yang menunjukkan adanya rasa bingung, atau suasana hati yang sedang bingung. Dalam serat Kalatidha terdapat satu indikator yang menunjukkan adanya ragam bingung. Berikut pemaparan data terkait ragam bingung yang digunakan Ranggawarsita.

6) Mundhak apa aneng ngayun 'apa keuntungan menjadi pemimpin'. (Andjar Any, 1989: 26, serat Kalatidha pupuh 4 gatra 6)

Data tersebut menunjukkan adanya ragam bingung. Rasa bingung yang dirasakan Ranggawarsita ditandai dengan kata apa'apa'. Kata tersebut menunjukkan bahwa Ranggawarsita mengalami rasa bingung sehingga menimbulkan pertanyaan untuk dirinya sendiri. Jika dilihat dari konteks secara keseluruhan, Ranggawarsita merenung dan ia bertanya pada diri sendiri. Tampak dari kalimat sebelumnya, yen pinikir sayekti 'apabila dipikir benarbenar'. Kalimat tersebut mendukung indikator kata 'apa' yang menunjukkan adanya rasa bingung Ranggawarsita. Apabila dirangkai, kalimat menjadi yen pinikir sayekti, mundhak apa aneng ngayun 'apabila dipikir benar-benar, tambah apa di depan'. Maksud di depan dalam kalimat tersebut adalah pemimpin.

Jadi, berdasarkan fenomena yang ada, Ranggawarsita pada dasarnya sangat senang ketika mendapatkan kabar bahwa dirinya akan diangkat sebagai pemuka. Namun, ketika banyak orang-orang munafik yang mengakibatkan dirinya tidak jadi diangkat sebagai pemimpin, kemudian hati Ranggawarsita bingung. Bingung yang dirasakan dikarenakan rasa senang yang dikecewakan, kemudian ia berfikir yang menimbulkan pertanyaan bagi dirinya sendiri, sehingga rasa bingung itu muncul.

Ragam bingung pada dasarnya digunakan untuk mengekpresikan ketidakmantapan hati, sebagaimana dalam serat Kalatidha, ragam bingung menunjukkan ketidakmantapan hati Ranggawarsita untuk menerima kenyataan yang ada. Di satu sisi Ranggawarsita sangat senang ketika mendapatkan kabar akan diangkat sebagai pemuka, disisi lain ia juga berfikir apa gunannya menjadi pemuka bila hanya akan menimbulkan kesedihan. Hal itulah yang menjadikan rasa bingung muncul. 


\section{Ragam Mantap}

Ragam mantap merupakan variasi bahasa yang menunjukkan adanya kemantapan terhadap sesuatu, sehingga disampaikan dengan diksi atau varisasi bahasa yang menunjukkan rasa mantap. Dalam serat Kalatidha terdapat beberapa indikator data yang menunjukkan adanya rasa mantap, seperti pada data berikut.

7) Ratune ratu utama 'rajanya raja yang bijaksana'. (Andjar Any, 1989, p.25, serat Kalatidha pupuh 2 gatra 1)

Data 7) tersebut merupakan indikator adanya ragam mantap. Ragam mantap ditandai adanya pengulangan kata yaitu ratune ratu 'rajanya raja'. Ranggawarsita sangat mantap menyampaikan bahwa sesungguhnya raja pada masa itu adalah raja yang sangat baik, bijaksana, sehingga dikatakan sebagai raja utama. Kata utama 'utama' pada data tersebut juga menunjukkan adanya kemantapan hati Ranggawarsita. Kata 'utama' yang melekat pada kalimat tersebut memiliki banyak makna, antara lain raja yang baik, bijaksana, dermawan, cerdas, dan sebagainya.

\section{Ragam Bimbang}

Ragam bimbang merupakan variasi bahasa yang menunjukan adanya rasa bimbang, tidak mantap, atau tidak percaya diri bagi orang yang menuturkan atau menyatakan suatu hal. Dalam serat Kalatidha terdapat satu indikator data yang menunjukkan adanya ragam bimbang. Data tersebut sebagai berikut.

8) Melu edan ora tahan, yen tan melu anglakoni, boya kaduman melik 'ikut sesat tidak tahan, jika tidak ikut tersesat, tidak mendapat apa-apa'. (Andjar Any, 1989, p.26, serat Kalatidha pupuh 7 gatra 3, 4, dan 5

Data 8) tersebut terdapat ragam bimbang. Ragam bimbang menunjukkan rasa bimbang atau kebimbangan hati Ranggawarsita ketika akan memutuskan suatu hal. Pada data tersebut dipaparkan bahwa apabila ikut gila (menggila pada zaman rusak) pasti tidak akan tahan, namun sebaliknya apabila tidak larut dalam zaman gila, juga tidak akan mendapatkan apaapa. Hal tersebut yang menjadikan kebimbangan hati Ranggawarsita untuk menentukan pilihan. Rasa bimbang pada data tersebut ditandai dengan kata yen 'jika'. Kata tersebut menunjukkan bahwa Ranggawarsita masih berpikir, masih bimbang untuk menentukan sikap. Sikap mengikuti zaman edan 'gila' ataupun tetap sebagai orang yang baik. Ragam bimbang pada serat Kalatidha menunjukkan kebimbangan hati Ranggawarsita ketika akan memutuskan sesuatu. Namun, jika dilihat pada konteks pupuh berikutnya, Ranggawarsita tegas sebagai orang yang tidak larut dalam zaman edan 'gila'. Ia tetap menjadi pribadi baik.

Ragam Malu

Ragam malu merupakan variasi yang menyatakan rasa malu. Ragam malu dalam serat Kalatidha ditandai dengan diksi ataupun pilihan kata yang menunjukkan adanya rasa malu. Seperti pada data 9) berikut ini.

9) Kataman ing reh wirangi 'terkena rasa malu'. (Andjar Any, 1989, p.25, serat Kalatidha pupuh 3 gatra 4 )

Data 9) tersebut terdapat ragam malu, yaitu ditandai dengan kata wirang 'sangat malu'. Kata wirang 'sangat malu' memiliki nilai rasa yang lebih tinggi untuk mengungkapkan rasa malu, jika dibandingkan dengan kata isin 'malu' yang keduanya memiliki kemiripan makna. Pada konteks pupuh yang terdapat data 9) tersebut, diceritakan bahwa Ranggawarsita sangat terpukul, sangat sedih, bahkan sangat malu karena fitnahan orang, ataupun gunjingan orang-orang munafik yang bertujuan untuk menghancurkan citra Ranggawarsita dimata kerajaan, sehingga ia tidak jadi diangkat sebagai pemuka.

\section{Ragam Beku}

Ragam beku merupakan ragam yang tetap, maksudnya tidak akan berubah, atau sudah beku. Ragam ini dapat dijumpai dalam tembang. Ragam beku dalam tembang ditandai dengan aturan tembang seperti guru lagu, guru gatra, dan guru wilangan. Berdasarkan ketentuan tersebut, maka semua pupuh dalam serat kalatidha termasuk ragam beku, karena terikat oleh aturan tembang. Berikut contoh pembahasan ragam beku dalam serat kalatidha karya Ranggawarsita.

10) Ratune ratu utama, patihe patih linuwih, pra nayaka tyas raharja, panekare becikbecik, parandene tan dadi, paliyasing kalabendu,mandar mangkin andadra, rubeda angreribedi,beda-beda ardane wong sanegara "rajanya raja yang bijaksana, patihnya patih yang cerdas, semua punggawanya berhati baik,pemuka-pemuka masyarakat baik, namun tidak 
menjadikan, ketentraman di zaman yang penuh keragu-raguan, bahkan semakin merosot, permasalahan yang merepotkan, berbeda-beda nafsu dan keinginan orangorang dalam satu negara". (Andjar Any, 1989 , p.25, serat Kalatidha pupuh 2)

Data 10) tersebut merupakan contoh penggunaan ragam beku. Ragam beku ditandai dengan aturan penulisan tembang. Secara keseluruhan, pupuh dalam serat kalatidha karya Ranggawarsita merupakan pupuh tembang sinom, sehingga semua pupuh terikat oleh aturan tembang sinom. Secara struktur kebahasaan, data 10) tersebut tidak terikat oleh kaidah struktur kalimat, namun terikat oleh aturan penataan tembang. Aturan penataan tembang tersebut seperti guru lagu, guru gatra, dan guru wilangan. Guru lagu tembang sinom adalah a, i, a, i, i, $\mathrm{u}, \mathrm{a}, \mathrm{i}, \mathrm{a}$, guru wilangan masing-masing baris 8 , $8,8,8,7,8,7,8,12$, dan guru gatranya adalah 9.

Berdasarkan aturan tersebut, maka data 10) tersebut sudah beku, terikat oleh aturan. Apabila diubah, maka aturan tembang yang harusnya melekat sudah tidak terpakai lagi. Misalnya pada baris pertama ratune ratu utama 'rajanya raja utama', guru wilangan 8 , guru lagu a. Kemudian kata ratu 'raja' diganti dengan kata narendra 'raja', dan kata utama 'utama' diganti dengan utami 'utama', sehingga menjadi ratune narendra utami 'rajanya raja utama'. Data tersebut akan mengubah aturan tembang, karena guru wilangan menjadi 9, dan guru lagu berubah menjadi i, sehingga tidak beku lagi.

Contoh analisis tersebut juga dapat diterapkan pada semua pupuh. Seperti yang telah dipaparkan sebelumnya bahwa ragam beku dapat ditandai dengan aturan penulisan tembang, yaitu terikat oleh guru lagu, guru gatra, dan guru wilangan. Apabila aturan tersebut tidak digunakan, maka tembang yang ditulis tidak beku lagi, karena menyimpang dari kaidah penulisan tembang.

\section{Ragam Filosofis}

Ragam filosofis merupakan variasi yang menggambarkan pandangan hidup masyarakat. Dengan kata lain, ujaran atau tuturan merupakan sebuah filosofi yang dipercaya kebenarannya. Misalnya orang yang berbuat dosa atau mencelakai orang lain pasti akan mendapatkan balasannya. Dalam serat Kalatidha terdapat beberapa indikator data adanya ragam filosofis, seperti pada data 11) berikut ini.

11) Begja-begjane kang lali, luwih begja kang eling lawan waspada 'seberuntungberuntungnya yang lupa, lebih beruntung yang ingat dan waspada'. (Andjar Any, 1989, p.26, serat Kalatidha pupuh 7 gatra 9)

Data 11) tersebut merupakan ragam filosofis. Sampai saat ini, masyarakat khususnya masyarakat Jawa masih percaya terhadap filosofi bahwa orang yang selalu waspada pasti akan mendapatkan keberuntungan. Sekalipun orang yang lupa juga beruntung, namun tidak seberuntung orang yang ingat dan waspada. Dalam data di atas terdapat kata eling 'ingat'. Kata eling 'ingat' tersebut merujuk ingat kepada Tuhan. Jadi, masyarakat Jawa berpedoman penuh kepada Tuhan agar mendapatkan kemudahan hidup. Biasanya, data 11) tersebut diucapkan oleh orang tua kepada anaknya, atau orang yang lebih tua kepada orang yang lebih muda.

Ranggawarsita sebagai pujangga tentu tidak sembarangan menggunakan kata-kata atau diksi dalam karya sastranya. Diksi yang menggambarkan ragam filosofi disesuaikan dengan pemahaman masyarakat Jawa terkait proses hidup maupun fenomena kehidupan. Petuahpetuah Jawa yang diyakini kebenarannya diungkapkan dalam serat Kalatidha sebagai bentuk penenang diri untuk menyikapi permasalahan hidup yang di alami Ranggawarsita.

\section{Konteks Sosial Budaya dalam Serat Kalatidha} karya Ranggawarsita

Variasi bahasa dalam serat Kalatidha selain terdapat ragam filosofi yang diyakini masyarakat, juga mencerminkan konteks sosial budaya masyarakat pada waktu itu. Kebudayaan masyarakat dapat terpilah menjadi tujuh unsur kebudayaan, dan dalam serat Kalatidha ditemukan 5 konteks sosial budaya, yaitu bahasa, strata sosial, sistem pemerintahan/kepemimpinan, sistem religi/keyakinan, dan sistem pengetahuan. Kelima kontek sosial budaya tersebut tercermin dalam pupuh serat Kalatidha, dan dapat dianalisis berdasarkan diksi maupun ragam bahasa yang digunakan. Berikut pembahasan masing-masing konteks sosial budaya yang terdapat dalam serat Kalatidha karya Ranggawarsita. 


\section{Bahasa}

Bahasa sebagai bagian dari kebudayaan merupakan alat komunikasi masyarakat baik komunikasi lisan maupun tulis. Dalam serat Kalatidha, bahasa dapat dianalisis berdasarkan fungsi bahasa sebagai alat komunikasi. Maksudnya, Ranggawarsita menggunakan bahasa dalam menulis serat Kalatidha untuk mengkomunikasikan ataupun menyampaikan isi hatinya terkait dengan fenomena hidup yang ia alami pada masa itu. Jadi, bahasa sebagai bagian dari kebudayaan tercermin dalam semua pupuh serat Kalatidha, karena Ranggawarsita menyampaikan dengan bahasa tulis.

Bahasa dalam serat Kalatidha terdiri dari beberapa ragam, seperti yang telah dipaparkan pada pembahasan sebelumnya. Ragam-ragam tersebut memiliki fungsi masing-masing guna menyampaikan maksud Ranggawarsita. Ada ragam yang langsung dapat dimengerti, ada pula ragam yang perlu ditelaah untuk dapat dimengerti, seperti ragam sastra atau ragam indah yang identik dengan kata-kata kias.

Jadi dapat disimpulkan bahwa konteks sosial budaya yang tercermin melalui bahasa, terdapat dalam keseluruhan pupuh, karena Ranggawarsita menggunakan bahasa sebagai media komunikasi tulis. Bahasa yang digunakan oleh Ranggawarsita adalah bahasa Jawa kuno, sehingga untuk memahami bahasa tersebut diperlukan pengetahuan tentang bahasa Jawa kuno.

\section{Strata Sosial}

Konteks sosial budaya yang kedua terdapat dalam serat Kalatidha kaitannya dengan strata sosial. Konteks ini dapat dianalisis pada pupuh ke 2. Dalam pupuh 2 tampak adanya strata sosial masyarakat. Pupuh 2 serat kalatidha sebagai berikut.

12) Ratune ratu utama, patihe patih linuwih, pra nayaka tyas raharja, panekare becikbecik, parandene tan dadi, paliyasing kalabendu,mandar mangkin andadra, rubeda angreribedi,beda-beda ardane wong sanegara "rajanya raja yang bijaksana, patihnya patih yang cerdas, semua punggawanya berhati baik,pemukapemuka masyarakat baik, namun tidak menjadikan, ketentraman di zaman yang penuh keragu-raguan, bahkan semkin merosot, permasalahan yang merepotkan, berbeda-beda nafsu dan keinginan orang- orang dalam satu negara". (Andjar Any, 1989, p.25, serat Kalatidha pupuh 2).

Data 12) tersebut menunjukkan adanya strata sosial ataupun kelas sosial masyarakat. Hal tersebut tampak dari diksi yang digunakan, seperti ratu 'raja', patih 'menteri', nayaka 'pemimpin', dan panekar 'kepala daerah'. Katakata tersebut menunjukkan bahwa pada masa Ranggawarsita telah ada sistem pemerintahan hingga terbentuk kelas ataupun strata sosial. Strata sosial yang paling tinggi adalah ratu 'raja'. Raja dikelilingi oleh menteri, dan membawahi kepala daerah. Sebagai salah satu syarat terbentuknya suatu negara, maka harus ada warga, sehingga strata sosial dalam serat Kalatidha sangat tampak dengan adanya data tersebut.

Strata sosial menunjukkan adanya batasan-batasan. Raja yang menduduki kelas sosial tertinggi tentu kesehariannya lebih banyak berinteraksi dengan strata sosial tinggi pula seperti keluarga raja, menteri, dan kepala-kepala daerah. Namun hal tersebut tidak menutup kemungkinan raja untuk berinteraksi dengan masyarakat, karena diceritakan bahwa raja pada masa itu adalah raja yang baik, tampak dari kalimat ratune ratu utama 'rajanya raja utama'. Interaksi yang terjadi menunjukkan adanya kelas maupun strata sosial, yaitu raja sebagai pemegang strata sosial atas dan masyarakat sebagai pemegang strata sosial bawah.

\section{Sistem Pemerintahan/Kepemimpinan}

Sistem pemerintahan/kepemimpinan dalam serat Kalatidha karya Ranggawarsita menunjukkan bahwa pada masa Ranggawarsita telah terbentuk kehidupan politik. Hal ini tercermin dari banyaknya golongan-golongan munafik yang hidup disekeliling kerajaan dan gemar memfitnah bahkan menghalalkan segala cara untuk mendapatkan keuntungan pribadi. Konteks sosial budaya yang tercermin dari sistem pemerintahan ditandai dengan indikator data pada pupuh 1 dan pupuh 2. Masing-masing pupuh dibahas pada pembahasan berikut.

13) Mangkya darajating praja, kawuryan wus sunyaruri, rurah pangrehing ukara, karana tanpa palupi, atilar silastuti, sujana sarjana kelu, kalulun kalatidha, tidhem tandhane dumadi, ardayengrat dene karoban rubeda. 'sekarang kemasyuran negara, tampak sudah hilang, komunikasi telah rusak, karena tanpa keteladanan, meninggalkan kesantuan, para cendekiawan masa bodoh, terbe- 
lenggu zaman yang penuh keragu-raguan, hilang gairah kehidupan, terbebani banyaknya nafsu dan permasalahan'. (Andjar Any, 1989, p.25, serat Kalatidha pupuh 1)

Sistem pemerintahan pada data 13) pupuh 1 tersebut tercermin dari data darajating praja 'derajatnya negara', dan pangreh 'sistem pemerintahan'. Kedua data tersebut menunjukkan adanya sistem pemerintahan pada masa hidup Ranggawarsita. Syarat terjadinya suatu negara haruslah ada sistem pemerintahan. Raja sebagai kepala pemerintahan pada masa itu tentu memiliki cara ataupun langkah dalam memimpin negaranya. Langkah maupun cara tersebut terangkum dalam sistem pemerintahan.

Sistem pemerintahan sangat berpengaruh pada derajat suatu negara. Sistem pemerintahan yang baik tentu berdampak pula pada derajat negara dimata masyarakat maupun negara lain. Pada zaman Ranggawarsita diceritakan bahwa sistem pemerintahan telah rusak. Rusaknya sistem pemerintahan ini tidak disebabkan oleh raja yang kurang cakap maupun wakil-wakilnya yang tidak pandai. Namun, rusaknya sistem pemerintahan tersebut dikarenakan banyaknya golongan-golongan penghasut, orang-orang jahat yang tinggal disekeliling kerajaan. Orangorang tersebut lantas menebarkan isu-isu kebohongan sehingga berpengaruh pada sistem pemerintahan dan berdampak buruk pada derajat negara.

\section{Sistem Religi/Keyakinan}

Data terkait dengan sistem religi maupun keyakinan dalam serat Kalatidha sangat banyak ditemukan. Sistem keyakinan terdapat pada pupuh 6 , pupuh 7 , pupuh 8 , pupuh 9 , pupuh 10 , pupuh 11, dan pupuh 12. Secara berurutan, Ranggawarsita meletakkan konteks keyakinan pada pupuh 6 sampai 12. Berdasarkan keenam pupuh tersebut dapat disimpulkan bahwa pada masa Ranggawarsita juga sudah terdapat suatu keyakinan kepada Tuhan. Berikut pembahasan mengenai sistem religi/keyakinan yang terdapat dalam serat Kalatidha karya Ranggawarsita.

14) Keni kinarya darsana, panglimbang ala lan becik, sayekti akeh kewala, lelakon kang dadi tamsil, masalahing ngaurip, wahananira tinemu, temahan anarima, mupus pepesthening takdir, puluh-puluh anglakoni kaelokan 'bisa dijadikan contoh, penimbang baik dan buruk, tentunya banyak juga, kisah yang menjadi contoh, masalahnya hidup, sebagai sarana ditemukan, lebih baik menerima, menerima kepastian takdir, banyak sekali menjalani keanehan'. (Andjar Any, 1989, p.26, serat Kalatidha pupuh 6)

Pupuh tersebut menunjukkan adanya sistem keyakinan kepada Tuhan, tampak dari kalimat mupus pepesthening takdir 'menerima kepastian takdir'. Ketika sudah berbicara mengenai takdir, maka konteks yang terjadi adalah hubungan manusia dengan Tuhan. Ma-nusia tidak dapat menentukan takdir, karena hanya Tuhan yang bisa mengubah takdir manu-sia. Dalam konteks pupuh tersebut, Rangga-warsita menceritakan dirinya sebagai seorang yang menerima takdir Tuhan. Berdasarkan hal tersebut, jelas bahwa pada masa itu sudah ada sistem religi maupun keyakinan kepada Tuhan.

Sistem keyakinan juga ditunjukkan adanya data temahan anarima 'lebih baik menerima'. Data tersebut digunakan oleh Ranggawarsita untuk menyikapi permasalahan kehidupan yang ia rasakan. Data tersebut menunjukkan bahwa Ranggawarsita menyimpulkan lebih baik menerima segala bentuk keputusan. Menerima yang dimaksud adalah menerima keputusan Tuhan. Dengan kata lain, Ranggawarsita berpasrah diri kepada Tuhan.

\section{Sistem Pengetahuan}

Konteks sosial budaya yang tercermin dari sistem pengetahuan ditunjukkan dengan adanya diksi ataupun ragam bahasa yang berhubungan dengan konteks tersebut. Dalam serat Kalatidha, ditemukan sistem pengetahuan, tampak dari satu pupuh yaitu pupuh pertama. Pembahasan mengenai sistem pengetahuan tersebut sebagai berikut.

15) Mangkya darajating praja, kawuryan wus sunyaruri, rurah pangrehing ukara, karana tanpa palupi, atilar silastuti, sujana sarjana kelu, kalulun kalatidha, tidhem tandhane dumadi, ardayengrat dene karoban rubeda 'sekarang kemasyuran negara, tampak sudah hilang, komunikasi telah rusak, karena tanpa keteladanan, meninggalkan kesantuan, para cendekiawan masa bodoh, terbelenggu zaman yang penuh keragu-raguan, hilang gairah kehidupan, terbebani banyaknya nafsu dan permasalahan'. (Andjar Any, 1989, p.25, serat Kalatidha pupuh 1) 
Sistem pengetahuan dalam data 15) tersebut ditunjukkan oleh kata sujana 'orang pandai' dan sarjana 'berilmu'. Dahulu, siapapun yang memiliki ilmu ataupun pengetahuan lebih dapat disebut sebagai sarjana. Namun, pada saat ini kata 'sarjana' mengalami penyempitan makna. Penyempitan makna merupakan "gejala yang terjadi pada sebuah kata yang pada mulanya mempunyai makna yang cukup luas, kemudian menjadi terbatas hanya pada sebuah makna saja" (Chaer, 2002, p.142). Saat ini, Orang dapat disebut sebagai sarjana apabila telah menempuh dan menyelesaikan studi tingkat universitas. Kata 'sarjana' membuktikan bahwa pada zaman Ranggawarsita telah terdapat sistem pengetahuan.

Diceritakan pada pupuh tersebut, orangorang pandai dan memiliki pengetahuan lebih tidak menjamin redanya zaman penuh kesukaran dan kerusakan. Bahkan, pada pupuh di atas, orang pandai dan berpengetahuan malah hanyut dalam arus kalatidha. Sistem pengetahuan yang lebih tidak menjamin berakhirnya zaman rusak (kalatidha), tampak dari kalimat sujana sarjana kelu, kalulun kalatidha 'orang pandai diam membisu, terbuai zaman rusak'. Kalimat tersebut membuktikan bahwa pada masa Ranggawarsita memang sudah ada sistem pengetahuan, walaupun mungkin tidak diterapkan dalam pendidikan formal. Seperti yang telah dipaparkan sebelumnya, kata 'sarjana' mengalami penyempitan makna, sehingga orang pandai berpengetahuan pada masa Ranggawarsita dapat dikatakan sebagai sarjana. Dengan demikian dapat disimpulkan bahwa adanya sistem pengetahuan sebagai bagian dari konteks sosial budaya dalam serat Kalatidha karya Ranggawarsita ditunjukkan oleh diksi maupun ragam bahasa yang berkaitan dengan hal tersebut. Diksi tersebut yaitu 'sarjana' dan sujana yang keduanya merujuk pada pengertian orang yang berpengetahuan atau berilmu.

Berdasarkan pembahasan mengenai ragam dan konteks sosial budaya tersebut dapat disimpulkan bahwa peranan diksi maupun pilihan kata sangat berpengaruh dalam suatu karya sastra. Seperti yang dipaparkan Keraf (1999, p.87) "ketepatan pilihan kata mempersoalkan kesanggupan sebuah kata untuk menimbulkan gagasan-gagasan yang tepat pada imajinasi pembaca atau pendengar, seperti yang dipikirkan atau dirasakan oleh penulis atau pembaca". Berdasarkan pemaparan tersebut dapat disimpulkan bahwa peranan kata sangat penting untuk menjembatani maksud pengarang yang disampaikan dalam karya sastra, sehingga sampai pada pembaca. Namun, dalam hal ini sangat dibutuhkan peranan konteks dan makna sehingga pembaca karya sastra dapat memahami maksud pengarang.

Pilihan kata bahasa Jawa dapat dijumpai pada penggunaan ragam bahasa, seperti yang digunakan oleh Ranggawarsita dalam serat Kalatidha. Kenyataan yang ada bahwa dalam bahasa Jawa terdapat tingkatan tutur bahasa, sehingga pilihan kata yang ada sangat luas, dan masing-masing memiliki tingkatan-tingkatan tutur yang berbeda. Menyikapi hal tersebut, pengguna bahasa baik secara lisan maupun tertulis harus mampu memilah kata yang tepat digunakan, sehingga tidak terjadi kesalahan tingkat tutur bahasa.

Dalam serat Kalatidha, Ranggawarsita menggunakan bahasa Jawa kuno, sehingga untuk memahami isi yang tercermin dari ragam bahasa yang digunakan, dibutuhkan peranan konteks dan makna. Hal tersebut dilakukan mengingat bahwa bahasa Jawa kuno pada saat ini tidak lazim digunakan untuk berkomunikasi lisan, sehingga sangat jarang masyarakat mendengar dan menggunakan bahasa Jawa kuno. Bahasa Jawa kuno pada saat ini digunakan hanya pada situasi-situasi tertentu, misalnya digunakan oleh dalang dalam pewayangan, dan digunakan oleh MC pada upacara adat pernikahan Yogyakarta. Selain itu, bahasa Jawa kuno hanya digunakan dalam karya sastra lama, seperti pada serat Kalatidha karya Ranggawarsita.

Hasil penelitian mengenai ragam bahasa dalam serat Kalatidha kemudian disusun menjadi soal dan diteskan di tingkat sekolah menengah pertama. Tujuannya adalah untuk mengetahui tingkat kerelevanan ragam bahasa dalam serat Kalatidha tersebut apabila diajarkan pada siswa SMP. Mengingat bahwa dalam buku pegangan siswa yang berjudul Kaloka Basa terdapat materi yang diambil dari salah satu pupuh Kalatidha dengan menggunakan aksara Jawa. Kenyataan tersebut yang dijadikan sebagai salah satu alasan penelitian tentang relevansi ini dilakukan. Adapun instrument dalam penelitian ini adalah tes. Hasil dari tes dipaparkan pada pembahasan berikut, sehingga dapat pula ditarik kesimpulannya. 
Relevansi Diksi Serat Kalatidha karya Ranggawarsita dalam Pembelajaran Bahasa Jawa Siswa Kelas IX SMP N 7 Yogyakarta

Diksi yang digunakan dalam serat Kalatidha disusun menjadi naskah soal dan diteskan pada siswa kelas IX SMP N 7 Yogyakarta. Tes dilaksanakan pada tanggal 25 Februari 2013 sampai dengan tanggal 2 Maret 2013. Tes dilakukan pada siswa kelas IX, terbagi menjadi 6 kelas dengan masing-masing peserta yaitu kelas IX A sebanyak 32 siswa, IX B 32 siswa, IX C 32 siswa, IX D 31 siswa, IX E 31 siswa, dan kelas IX F dengan jumlah peserta sebanyak 31 siswa. Jumlah keseluruhan siswa yang mengikuti tes sebanyak 189 siswa.

Bentuk soal yang diteskan adalah pilihan ganda dengan jumlah soal sebanyak 50 butir soal. Pekerjaan siswa dikoreksi menggunakan software anatesV4. Penggunaan software anatesV4 ini bertujuan untuk mempermudah dalam proses analisis data. Selain itu, dengan bantuan software, akan mengurangi tingkat kesalahan pengoreksian, seperti yang sering terjadi pada pengoreksian secara manual.

Berdasarkan hasil tes yang dapat disimpulkan bahwa tingkat ketuntasan nilai siswa masih sangat kecil. Siswa yang mencapai nilai tuntas hanya 5 dari 189 siswa yang mengikuti tes. Hal tersebut menunjukkan bahwa tes yang diberikan masih sangat sulit diterima oleh siswa. Pedoman yang digunakan untuk mengetahui tingkat ketuntasan nilai siswa adalah KKM yang diberlakukan di sekolah. Nilai KKM mata pelajaran bahasa Jawa di sekolah khususnya di SMP N 7 Yogyakarta adalah 75. KKM tersebut dapat dimaknai jika siswa mencapai nilai kurang dari 75, maka siswa belum tuntas. Sedangkan apabila siswa mencapai nilai lebih dari atau sama dengan 75, maka siswa telah tuntas atau mencapai kriteria ketuntasan.

Hasil tersebut tersebut menunjukkan bahwa diksi serat Kalatidha kurang tepat atau bahkan tidak tepat jika digunakan sebagai materi ajar bahasa Jawa bagi siswa tingkat SMP. Mengingat hasil tes siswa sangat kurang, hanya 5 siswa yang mencapai tingkat ketuntasan. Untuk itu, guru ataupun pembuat buku pegangan siswa harus hati-hati ketika memilih dan menggunakan materi ajar. Jangan sampai materi yang diberikan menyimpang dari pemahaman siswa, sehingga siswa merasa kesulitan untuk menyerap materi yang disampaikan.

Hasil tes yang kurang dapat dimungkinkan karena faktor tingkat kesulitan bahasa yang digunakan dalam serat Kalatidha. Bahasa yang digunakan dalam serat Kalatidha adalah bahasa Jawa kuno, dan bukanlah konsumsi bahasa bagi siswa tingkat SMP. selain itu, sasaran pembaca naskah Kalatidha tidak asal, walaupun naskah tersebut ditulis untuk umum. Tidak semua orang mampu memahami karya pujangga, lebih-lebih apabila karya tersebut dituliskan dengan bahasa Jawa kuno, yang bukan merupakan bahasa keseharian. Selain itu, pada tingkat SMP tentu diksi maupun penguasaan kosakata bahasa Jawa sebatas kosakata yang digunakan dalam kehidupan sehari-hari. Sementara itu, dalam naskah Kalatidha, diksi-diksi yang digunakan sangat jarang didengar oleh siswa, sehingga kurangnya hasil tes tersebut adalah sesuatu yang wajar.

Hasil penelitian ini dapat digunakan sebagai koreksi terhadap buku pegangan yang telah beredar dan di dalamnya terdapat materi dari pupuh Kalatidha. Buku yang telah beredar terdapat materi pupuh jaman edan dan ditulis dalam aksara Jawa. Hal tersebut menimbulkan banyak masalah bagi siswa. Fenomena yang ada bahwa siswa sangat kesulitan membaca aksara Jawa. Apalagi yang digunakan sebagai bacaan adalah pupuh Kalatidha yang menggunakan bahasa Jawa kuno. Siswa akan mengalami kesulitan yang lebih, mulai dari membaca aksara Jawa, bahasa Jawa kuna yang asing bagi siswa, dan pemahaman mengenai isinya.

Apabila pupuh Kalatidha ini tetap digunakan sebagai materi ajar, maka guru harus pandai menyikapi dengan mengubah pupuh menjadi sebuah bacaan dengan bahasa yang mudah dicerna tanpa mengubah isi dari pupuh tersebut. Hal ini tentu sangat menuntut ketrampilan guru sebagai fasilitator pendidikan dalam menyiapkan materi ajar, agar materi ajar yang diberikan sesuai dengan kemampuan siswa. Mungkin pupuh Kalatidha ini dapat disampaikan secara langsung tanpa diubah menjadi bacaan, namun pada tingkat pendidikan di atas SMP, mungkin SMA atau perguruan tinggi.

Kaitannya dengan nilai sosial budaya, tentu akan sesuai apabila digunakan sebagai materi pembelajaran. Mengingat isi dari serat Kalatidha menceritakan tentang sistem pemerintahan dan kepemimpinan. Hal ini sesuai jika dibelajarkan pada siswa, nantinya dapat dihubungan dengan pembentukan karakter peserta didik. Selain itu, nilai religi dalam serat Kalatidha juga sesuai apabila disampaikan dalam pembelajaran budi pekerti. Namun, semua itu harus disampaikan dengan bahasa yang mudah 
dipahami siswa, bukan dengan bahasa Jawa kuno, atau bahasa asli yang menyusun serat Kalatidha.

Melihat hasil tes siswa, peneliti menyarankan agar guru memberikan materi kaitannya dengan kosakata Jawa kuno. Hal tersebut dapat dilakukan melalui pembelajaran cerita pendek, puisi, dan tembang. Dengan demikian siswa dapat mengetahui kosakata-kosakata Jawa kuno, atau kosakata yang tidak lazim digunakan dalam komunikasi lisan.

\section{SIMPULAN DAN SARAN}

\section{Simpulan}

Berdasarkan hasil analisis yang telah dilakukan pada serat Kalatidha karya Ranggawarsita dapat disimpulkan bahwa terdapat beberapa jenis ragam bahasa dalam serat Kalatidha. Ragam yang digunakan dianalisis dan dikategorikan berdasarkan teori ragam.

Adapun jenis ragam yang terdapat dalam serat Kalatidha karya Ranggawarsita yaitu ragam tidak resmi, ragam sastra, ragam jengkel, ragam sedih, ragam senang, ragam bingung, ragam mantap, ragam bimbang, ragam malu, ragam beku, dan ragam filosofis. Kriteria ragam dalam teori yang tidak ditemukan dalam serat Kalatidha yaitu ragam resmi, ragam marah, dan ragam kreatif. Ragam yang paling banyak ditemukan dalam serat Kalatidha adalah ragam sastra atau ragam indah. Hal ini sejalan dengan serat Kalatidha sebagai salah satu bentuk karya sastra yang tentunya menggunakan kosakata atau variasi bahasa yang memiliki nilai sastra lebih.

Ragam yang terdapat dalam serat Kalatidha menunjukkan identitas sosial budaya masyarakat pada waktu itu. Berdasarkan analisis yang telah dilakukan, konteks sosial budaya masyarakat yang ditunjukkan oleh Ranggawarsita melalui serat Kalatidha antara lain bahasa, strata sosial, sistem pemerintahan, sistem religi/keyakinan, dan sistem pengetahuan.

Bahasa ditunjukkan atas dasar fungsi bahasa sebagai alat komunikasi, sehingga tampak dari serat Kalatidha secara keseluruhan. Strata sosial tampak dari adanya tingkatan-tingkatan sosial seperti raja, patih, pejabat daerah, dan sebagainya. Sistem pemerintahan dapat dianalisis berdasarkan isi serat Kalatidha yang berisikan mengenai pemerintahan pada masa hidup Ranggawarsita. Sistem keyakinan atau konteks religi ditunjukkan oleh diksi-diksi yang berhubungan seperti adanya kata Gusti, Hyang
Suksma, dan Pangeran yang ketiga kata tersebut mengagungkan nama Tuhan. Sistem religi ini merupakan konteks sosial budaya yang paling banyak ditemukan dalam serat Kalatidha, karena separuh dari serat Kalatidha terdapat konsep keyakinan. Sementara itu, sistem pengetahuan dapat dianalisis berdasarkan kosakata yang menunjukkan adanya sistem pengetahuan, misalnya kata sujana dan sarjana yang keduanya digunakan untuk menyebutkan orang yang pandai atau memiliki wawasan luas.

Hasil dari penelitian kaitannya dengan relevansi serat Kalatidha dalam pembelajaran bahasa Jawa menunjukkan bahwa serat Kalatidha tidak relevan apabila digunakan sebagai materi ajar tingkat SMP. Hal ini terbukti dari banyaknya siswa yang mencapai tingkat ketuntasan ketika dilakukan tes. Siswa yang tuntas hanya 5 dari 189 siswa. Tingkat ketuntasan yang digunakan sebagai pedoman adalah KKM bahasa Jawa yang diberlakukan sekolah yaitu 75. Angka tersebut dapat dimaknai bahwa siswa dikatakan tuntas ketika mencapai nilai lebih dari atau sama dengan 75 , dan siswa belum tuntas apabila nilai yang dicapai kurang dari 75 .

Hasil penelitian menunjukkan bahwa serat Kalatidha terlalu berat apabila diajarkan secara utuh pada siswa tingkat SMP. Mungkin serat Kalatidha dapat diterima pada tataran pendidikan di atasnya, yaitu SMA dan perguruan tinggi. Dengan demikian, serat Kalatidha tidak relevan jika diajarkan pada siswa SMP.

\section{Saran}

Berdasarkan penelitian yang telah dilakukan, maka disarankan bagi pembelajar khususnya bidang linguistik untuk tidak selalu menyamakan istilah ragam dengan variasi. Dengan demikian, diharapkan kedepan tidak terjadi kesimpangsiuran makna antara ragam dan variasi. Dalam bidang kaji sosiolinguistik, ragam merupakan bagian dari variasi bahasa.

Kaitannya dengan pembelajaran, ragam dalam serat Kalatidha karya Ranggawarsita tidak sesuai jika diberikan pada siswa tingkat SMP. Oleh karena itu, disarankan agar tim pembuat materi atau guru bidang studi untuk berhati-hati ketika menentukan materi ajar, sehingga siswa tidak direpotkan. Guru harus melakukan analisis kebutuhan siswa dengan berpedoman pada kurikulum, sehingga materi yang nantinya diberikan tepat dan sesuai.

Selain itu, disarankan kepada sekolah melalui guru mata pelajaran bahasa Jawa untuk sesekali memberikan materi kaitannya dengan 
kosakata. Walaupun kosakata ini tidak berdiri sendiri dalam materi ajar, namun guru dapat menyikapi melalui pembelajaran cerkak, geguritan, ataupun karya sastra lainnya. Dengan demikian, paling tidak siswa pernah belajar kosakata sehingga dapat berguna ketika bersosialisasi dan berinteraksi dengan masyarakat yang menggunakan bahasa Jawa.

\section{DAFTAR PUSTAKA}

Andjar Any. (1989). Rahasia ramalan Jayabaya Ronggawarsita dan Sabda Palon. Semarang: Aneka Ilmu.

Brannen, Julia. (2005). Memadu metode penelitian kualitatif dan kuantitatif. Yogyakarta: Pustaka Pelajar.
Chaer, Abdul. (2002). Pengantar Semantik Bahasa Indonesia. Jakarta: Rineka Cipta.

Keraf, Gorys. (1999). Diksi dan gaya bahasa. Jakarta: PT Gramedia Pustaka Utama.

Koentjaraningrat. (2009). Pengantar Ilmu Antropologi. Jakarta: Rineka Cipta.

Padmosoekotjo. (1958). Ngengrengan kasusastran Jawa I lan II.Yogyakarta: Hien Hoo Sing. 